\title{
Evaluation of the Temperature in the Painting Process on the Mechanical Properties of Polypropylene used in Automotive Bumpers
}

\author{
Thiago R. Azevedo ${ }^{1}$, Márcio E. Silveira ${ }^{1, *}$, Alysson L. Vieira ${ }^{2}$, Tulio hallak Panzera ${ }^{1}$, \\ André Luis Christoforo ${ }^{3}$, Luciano Donizeti Varanda ${ }^{4}$, Francisco Antonio Rocco Lahr ${ }^{5}$ \\ ${ }^{1}$ Department of Mechanical Engineering, Federal University of São João del-Rei, São João del-Rei, 36307-352, Brazil \\ ${ }^{2}$ PUC-MG, Contagem, 32310-400, Brazil \\ ${ }^{3}$ Department of Civil Engineering, Federal University of São Carlos, São Carlos, 13565-905, Brazil \\ ${ }^{4}$ Department of Material, Engineering School of São Carlos (EESC/USP), São Carlos, 13566-590, Brazil \\ ${ }^{5}$ Department of Structural Engineering, Engineering School of São Carlos (EESC/USP), São Carlos, 13566-590, Brazil
}

\begin{abstract}
The automotive components made of polymers are very sensitive to temperature variation, either during its application in the vehicle or in some stage of manufacture of the component. The automotive bumpers, made of polypropylene during the process of painting, undergo a heater. This process is harmless to metals used in the body of the car, which also undergo heater because it is insensitive to the process of temperatures. However, according to the temperature (even moderate) and duration of the exposure, it can modify considerably the mechanical properties of some polymers. The main objective of this work was to assess whether the painting process of automotive bumpers can change its mechanical properties. Tensile, bending and micro-hardness tests were carried out in samples of bumper with the paint process (temperature) and crude, showing that the process can influence the final mechanical behavior of the component.
\end{abstract}

Keywords Automotive Polymer, Mechanical Tests, Young's Modulus

\section{Introduction}

Polymers are macromolecules composed of smaller structural units (monomers). Industrial polymers are made of synthetic resins, manufactured through raw natural materials, like petroleum, natural gas and coal. Their producing uses $5 \%$ of the mundial commercial petroleum [1]. The polymers can be classified in three types:

- Thermoplastics: is one most found kind of plastic in the market. Can be more often fused and dissolve in another solvents. Soon, recycling is possible, feature fairly wishful today. Examples: polyethylene, polypropylene, poly (ethylene terephthalate), polycarbonate, polystyrene, poly (vinyl chloride), poly (methylmethacrylate), and others.

- Thermosets (or thermosetting): Are rigid and weak, being more stable at temperature variance. Once ready, can not to fuse more. The heating of the finished polymer promote a material decomposition before their fusion, turning more complicated the recycling. Examples: Bakelite, polyester, epoxy.

Elastomers: a medium class between thermoplastics and

* Corresponding author:

msilveira@ufsj.edu.br (Márcio E. Silveira)

Published online at http://journal.sapub.org/ijme

Copyright (C) 2014 Scientific \& Academic Publishing. All Rights Reserved thermosetting: cannot be fused, but shows high elasticity, not being rigid like thermosetting. Recycling is not easy due their fusion incapacity. Examples: raw rubber, neoprene.

Although exist a high polymeric materials variety, there are a selected number of products, called "engineering plastics", representing $70 \%$ of the total consume. In the automotive industry, polymers has a great perfomance due the low cost, low density, corrosion resistance and easy manufacturing of complex shapes, representing about $10 \%$ automobile total weight. By volume, however, plastics have an important presence in modern automobiles making of automotive industry the fourth largest consumer of plastic [2].

Plastics appeared with force in the first attempts to make lighter car for fuel consumption reasons, in front of oil crises of 1973 and 1976 [3]. Followed of a rapid conquests decade, starting with the vehicle's interior and bodywork, first in place of wood and metal, then moving to form new accessories linked to the introduction of electronics, from 80 's. In fact, for 15 years plastics have been grown their effective in automobile total weight.

In the last decades, plane iron used in the wagons have been had a great competition by light materials which shows been more light in corrosion resistance, like plastics and non-steel metals (aluminum, copper, zinc, manganese) [4].

The polypropylene (PP) is the most used polymer in the 
automotive industry, corresponding for about one third of the plastic used in the automobile [4]. Being thermoplastic, their recycling over $P P$ recycled addition to raw $P P$, have been obtained good results even in mechanical properties as economics factors [5].

The use of numerical simulation tools, based on Finite Element Methods in the automotive components project is fundamental for the fast project development, downsizing costs and time reducing for the new market product. However for the simulation shows perfectly the physical phenomenon is important which the constitutive model been appropriate by the component material. Actually most polymers are modeled using constitutive models of metals. Thus this approach can take considerable mistakes in the project, principally great strain events, plasticity, temperature variation and hate of strain $[6,7]$.

The development and calibration of visco-elastoplastic constitutive models appropriated for numerical simulation of thermoplastics consists of goals to be achieved in future works, making necessary a priori full knowledge of the mechanical properties of polymers so that they can be calibrated efficiently.

The automotive components made of polymers, in particular thermoplastics are very sensitive to temperature variation, both during your application in the vehicle or in some stage of manufacture of the component. The automotive bumpers, made of polypropylene, during your painting process go through a drying oven, the average temperature of $120^{\circ} \mathrm{C}$. This process is harmless to the metals used in the car body, which also pass through greenhouses, since they are insensitive to process temperatures. Some metals, in effect Bake Hardening, may even have your mechanical strength increased during the painting process. However, this temperature range (moderate), depending on exposure time, can significantly alter the mechanical properties of some polymers.

The principal objective of this study is to assess whether the temperature contained in the process of painting some automotive bumpers can change their mechanical characteristics. Once a piece is projected to have a certain mechanical behavior, these properties should not be changed during the painting process, risking fender not has your optimum pre- establishment during the design phase, as in event of an impact (crash test). At this stage of the study, samples were collected bumpers that went through the paint and other raw (unpainted) for carrying out the tensile test, bending and micro hardness in order to evaluate the elastic modulus, the maximum stress and the total elongation of the materials investigated.

\section{Methodology}

To ensure the correct sizing of the samples, the test samples were machined using a milling cutter CNC, with dimensions established by normative standards ASTM D638 [8] (tensile) and ASTM D790 [9] (bending), specific for polymeric materials. In tensile tests were used six specimens, three raw samples and three painted, both referring to Type V by ASTM D638 [8] (Figure 1). The dimension type V was chosen for be smaller than the type I (most frequent), designed for characterization of materials to be used in confined environments such as ovens and stove. For bending tests were taken two samples, a crude one and painted with dimensions of $115 \times 10 \times 2 \mathrm{~mm}$, and the micro-hardness tests were used raw samples 6 and 6 samples painted.

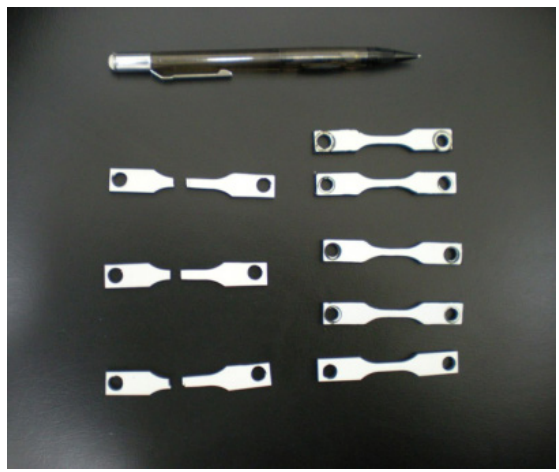

Figure 1. Samples of type V bumper painted

For tensile tests used a machine EMIC model DL500, with a maximum capacity of $500 \mathrm{Kgf}$. The specimens mentioned above were arrested and subjected to the clutches and continually increasing uniaxial displacements until failure (Figure 2). The speed of testing was $5 \mathrm{~mm} / \mathrm{min}$. Ultimately, with data recorded on the applied load versus the displacement was possible to obtain the stress $\times$ strain curve of the material.

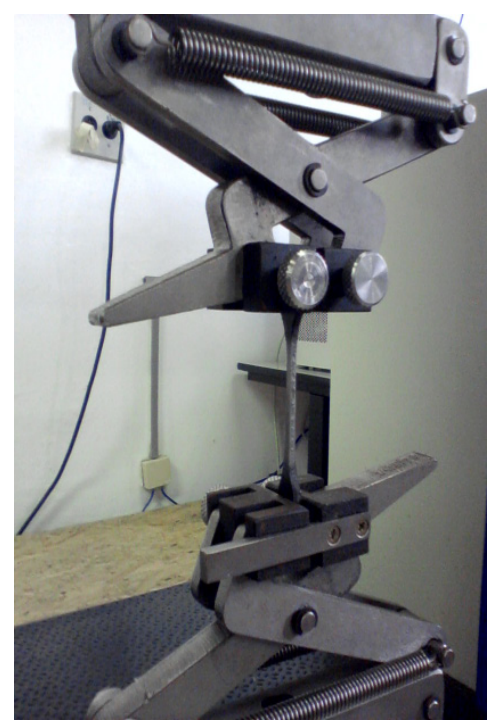

Figure 2. Tensile Test (raw sample)

With the aim of calculating the modulus of elasticity of the polymer was made a bending testing (Figure 3). Following the procedure cited in ASTM D790 [9], were tested six samples, three already undergone a painting process and the other not. The essay was performed to ensure that the stresses and strains undergone by specimen stay within the elastic range. 


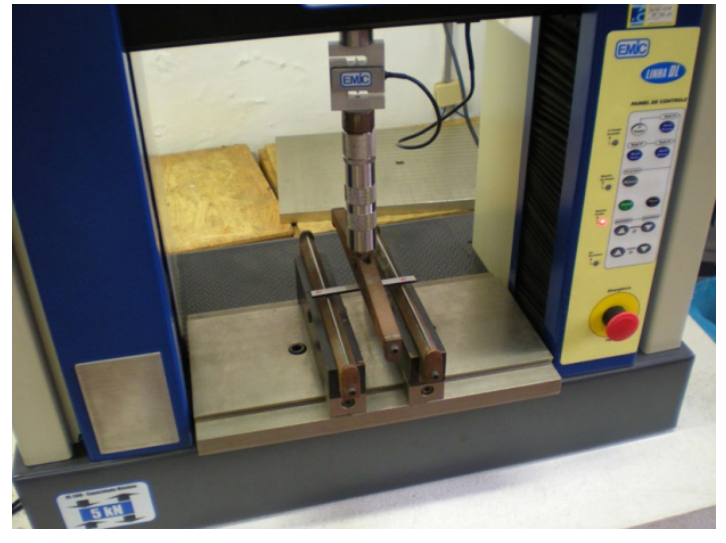

Figure 3. Bending testing

Considering small deformations and that the specimen behaved as an Euler-Bernoulli beam, it was possible to calculate the bending modulus, using the equation of the line deflection elastic beam (Equation 1), where $\mathrm{E}$ is the elasticity module, $\mathrm{L}$ is the length, $\mathrm{b}$ is the breadth, $\mathrm{d}$ is the thickness and $\mathrm{m}$ is the inclination of the curve load $\times$ displacement of the bending essay.

$$
E=\frac{L^{3} m}{4 b d^{3}}
$$

The value of hardness of a plastic comes from depth of penetration of an identador in the material under the action of a load. This assay was done in a ultra-micro hardness DUH $211 \mathrm{~S}$ in order to obtain not only the hardness of the polymer but also your modulus of elasticity to assess with the results of the bending test. Raw samples were assayed, sanded and painted (polished), and the modulus of elasticity (E) obtained in accordance with Equation 2 [10], being $E_{f}$ and $v_{f}$ the modulus of elasticity and Poisson coefficient respectively the penetrator, and $v_{S}$ the coefficient of Poisson's sample tested. The elastic modulus $\mathrm{E}_{\mathrm{c}}$ combined, restrained in Equation 2 may be calculated using the relationship between the indenting force $(\mathrm{F})$ and the contact depth $\left(h_{c}\right)$, as expressed in Equation 3.

$$
\begin{gathered}
E=\left(1-v_{s^{2}}\right)\left(E_{c}-\frac{E_{f}}{1-v_{f^{2}}}\right) \\
E_{c}=\frac{3 F h_{c^{-3 / 2}}}{8 \sqrt{2} \sqrt{r}}
\end{gathered}
$$

\section{Results}

The graphs presented in the Figures 4 and 5 shown the stress $\times$ strain curve relating the test specimens of the conditions without and with painting process respectively.

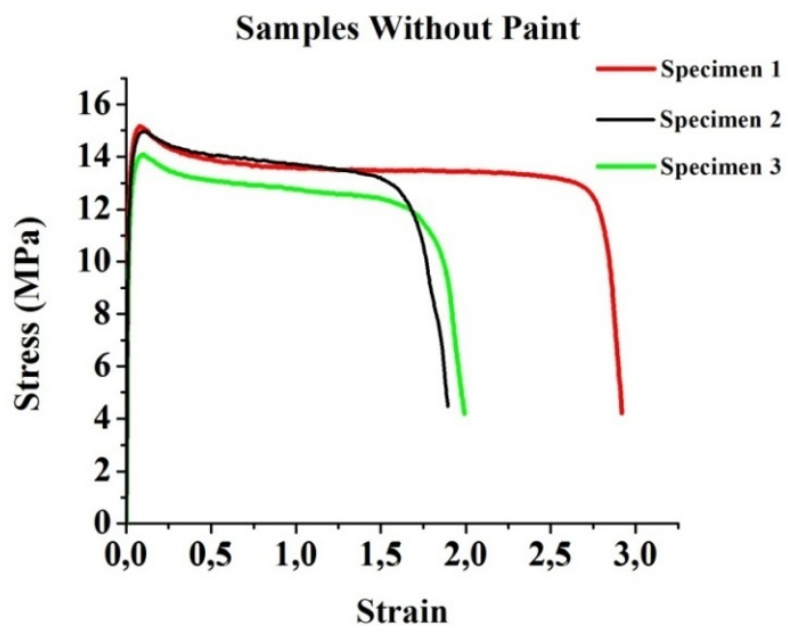

Figure 4. Curves stress $\times$ strain of specimens without the painting process (raw) obtained from uniaxial tensile

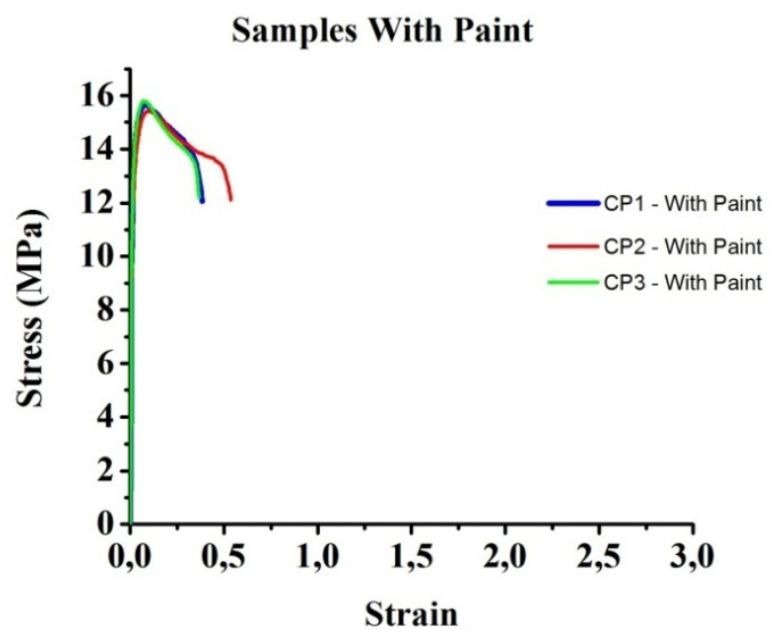

Figure 5. Curves stress $\times$ strain of tests of specimens with the painting process obtained from uniaxial tensile

Analyzing the graphs of Figures 4 and 5 it is observed that samples that passed through the painting process are less ductile, with a total elongation of about $80 \%$ lower than raw samples. The values of maximum stress, was observed a small increase in the samples with paint regarding the unpainted of 14,7MP for 15,7 MPa on average (6,80\%).

Table 1 presents the average values of elastic modulus obtained from uniaxial tensile tests in the specimens with and without the painting process.

Table 1. Modulus of elasticity (MPa) tensile tests

\begin{tabular}{cc}
\hline Specimen & Modulus of Elasticity \\
\hline unpainted & $1121 \pm 63$ \\
painted & $1412 \pm 49$ \\
Difference & $26 \%$ \\
\hline
\end{tabular}

The bending tests showed that the samples painted presented modulus elasticity greater than the raw, as shown in Table 2. 
Table 2. Modulus of elasticity (MPa) of bending testing

\begin{tabular}{cc}
\hline Specimen & Modulus of Elasticity \\
\hline unpainted & $966 \pm 42$ \\
painted & $1209 \pm 58$ \\
Difference & $25 \%$ \\
\hline
\end{tabular}

With the micro-hardness testing was possible to obtain the results of tensile modulus for the samples painted and raw (Table 3). The results show that the painting process resulted changes in mechanical properties of materials.

Table 3. Modulus of elasticity (MPa) of micro-hardness testing

\begin{tabular}{cc}
\hline Specimen & Modulus of Elasticity \\
\hline unpainted & $844 \pm 6$ \\
painted & $1078 \pm 47$ \\
Difference & $27 \%$ \\
\hline
\end{tabular}

\section{Conclusions}

The results of the experiments showed that the painting process can drastically reduce the total elongation of the polypropylene used in automotive bumpers, reducing the ductility of the material and, consequently, its toughness. This can be crucial in a project, due to automobile bumper having as main characteristic energy absorption in case of impact with pedestrians. The maximum stresses values showed little variation between samples and raw painted, since the modulus of elasticity of the polypropylene painted showed a marked increase over the result obtained with the raw samples. These results were also observed using the bending tests and micro-hardness.

The values of the elastic bending modulus and tensile in polypropylenes with and without the painting process showed behavior similar to that found in the work of [11], with $10 \%$ difference between the two.

Assays were performed developed at room temperature $\left(25^{\circ} \mathrm{C}\right)$ and at speeds quasi-static $(5 \mathrm{~mm} / \mathrm{min})$. The next phase of this work will assess the behavior of this polymer (painted and raw) considering variations of temperature and strain rate in order to eventually be able to calibrate a visco-elastoplastic model for computer simulations.

\section{REFERENCES}

[1] Piva, A. M.; Wiebeck, H. Reciclagem do Plástico. São Paulo, SP. Editora Artliber, 2004.

[2] Dorneles Filho, A. M. L. Critérios na seleção de plásticos de engenharia para aplicações em veículos populares no Brasil. Dissertação de Mestrado em Engenharia Automotiva Universidade de São Paulo, 190 p., 2006.

[3] Medina, H. V. Desenvolvimento de novos polímeros: uma ferramenta para os avanços na indústria automobilística. Revista Plástico Industrial, Ano IV, No 48 - Agosto, pp 108-120, 2002.

[4] Fontana, M. A evolução de materiais na indústria automobilística: o caso Volkswagen caminhões e ônibus. Dissertação de Mestrado - Universidade Federal Fluminense, Niterói, 2005.

[5] Fernandes, B. L., Domingues, A. J. Caracterização mecânica de polipropileno reciclado para a indústria automotiva. Polímeros: Ciência e Tecnologia. Vol. 15, N. 2, 2007.

[6] Lee, K.-S., Park, S.J., Kim, Y.S., Kim, J.S. Tensile properties of plastics used in automotive instrument panel over some ranges of strain rates and temperatures. International Forum on Strategic Technologies (IFOST 2006), 2006.

[7] Daiyan, H., Grytten, F., Andrreassen, E., Lyngstad, O. V., Osnes, H., Gaarder, R. H., Hinrichsen, E.L. Numerical simulation of low-velocity impact loading of polymeric materials. In 7th European LS-DYNA conference, 2009.

[8] American Society for Testing and Materials. D638 - Standard Test Method for Tensile Properties of Plastics. ASTM, USA, 2003.

[9] American Society for Testing and Materials. D790 - Standard Test Methods for Flexural Properties of Unreinforced and Reinforced Plasticsand Electrical Insulating Materials. ASTM, USA, 2003.

[10] Brunetti, C.; Leite, M. V.; Pintaúde, G. Modelos para Determinação do Módulo de Elasticidade de Ligas Metálicas Utilizando Ensaios de Penetração Instrumentada. Proveniente do Congresso Anual da ABM, 60, 2005, Belo Horizonte, MG. São Paulo: ABM, 2005.

[11] Da Luz, S. M.; Gonçalves, A. R.; Del'arco, A. P. Microestrutura e propriedades mecânicas de compósitos de polipropileno reforçado com celulose de bagaço e palha de cana. Revista Matéria, v. 11, n. 2, pp. $101-110,2006$. 